\title{
Registros privados de uma vida pública: o diário íntimo de Altino Arantes
}

Robson Mendonça Pereira*

Sonia Maria de Magalhães*

\section{RESUMO}

O artigo tem por objetivo apresentar as possibilidades de pesquisa contidas no diário íntimo de Altino Arantes, governador do Estado de São Paulo (1916-1920). Trata-se de uma fonte praticamente inédita guardada no Arquivo do Estado de Sáo Paulo, que nessa análise contempla os conflitos da oligarquia paulista no alvorecer da República.

Palavras-chave: diário íntimo; República; São Paulo; poder; oligarquia.

\section{ABSTRACT}

The article presents the research possibilities contained in the journal of Altino Arantes, governor of São Paulo State from 1916 to 1920. Stored in the Archives of the State and still unpublished, the journal contemplates the conflicts of São Paulo's oligarchy at the dawn of the Republic.

Keywords: journal; Republic; São Paulo; power; oligarchy. 


\section{Escrita autorreferencial e estratégias autobiográficas}

A noite já avançava quando Altino Arantes sentou-se à frente de sua escrivaninha, ajeitou-se na cadeira, abriu um caderno, colocou a pena no tinteiro e, em seguida, escreveu de maneira solene na primeira página: Meu diário — registro intimo de fatos e de impressóes. ${ }^{1}$ Após um pequeno introito, passa a descrever longamente os eventos e todas as sensaçóes que o tomaram de assalto naquele longo e exaustivo dia que parecia nunca terminar:

10 de maio de 1916, segunda-feira: minha posse na presidência do Estado.

No tumultuar das impressóes desencontradas, que este acontecimento levanta em meu atribulado espírito, duas se destacam e dominam todas as outras: uma grande surpresa e uma imensa, acabrunhada saudade (...). Surpresa da qual me não refiz ainda, ao ver-me, antes dos quarenta anos de idade, elevado à suprema magistratura de meu Estado natal, sem que eu descubra em mim méritos para tanto, sem que tenha visado jamais, nas minhas atitudes e conduta públicas, tão alta investidura. Não consigo explicar humanamente o estranho caso; e, por isso, a minha alma de crente prefere, singelamente, atribuir à proteçáo superior de Deus, que nunca me faltou, mas essa dádiva — generosa é certo, compreensiva talvez (...)

A intenção subjacente de Altino na feitura do diário aparece neste primeiro instante quando destaca o fato motivador do discurso autobiográfico. Evidentemente, não se trata de uma nota qualquer, mas de um momento significativo na trajetória de qualquer político com algum tipo de aspiração.

Altino se póe a registrar fatos cotidianos relacionados à sua atuação como homem público, revelando os bastidores da política paulista e consignando opiniōes sobre seus pares. Essas anotaçôes, relativas a momentos pessoais, estáo marcadas por circunstâncias de hesitação e sentimentos contraditórios diante de situaçóes adversas. Percebe-se no diário de Altino um projeto narrativo autorreferente no qual pretende mais do que consignar seus atos, apresentar uma leitura legitimadora de suas açóes e de seu papel como homem político diante da história.

A trajetória político-administrativa de Altino foi vertiginosa e se vinculou à de grandes líderes políticos paulistas da época, como o conselheiro Rodrigues Alves e Washington

\footnotetext{
${ }^{1}$ Arquivo do Estado de São Paulo (Aesp). Arquivo Privado de Altino Arantes (Apaa) — lócus: AP91.01.001. Volume 1.

${ }^{2}$ Francisco de Paula Rodrigues Alves (Guaratinguetá, 1848 - Rio de Janeiro, 1919), conselheiro do Império com longa experiência política, ocupou a presidência da República entre 1902 e 1906, tendo promovido uma reforma modernizadora na capital federal. Ocupou a presidência de Sáo Paulo entre 1912 a 1916. Seria eleito presidente da República em 1918, mas impedido de tomar posse, morre no início do ano seguinte devido a complicações da gripe que havia contraído.
} 
Luís. ${ }^{3}$ Por meio de uma análise pormenorizada de seu diário é possível perceber o universo de valores desta elite política em uma fase na qual começavam a se defrontar com as tensóes sociais provocadas pelos movimentos sociais e de modernização urbana do período. A agitação provocada pela Primeira Guerra Mundial que desencadeia a crise da economia cafeeira, a turbulenta Greve Geral anarquista de 1917 e a pandemia de gripe espanhola de 1918 constituem alguns dos acontecimentos que se embaralham na narrativa de Altino de maneira a sustentar seu discurso e suas açôes como gestor.

A análise de diários envolve-se de peculiar especificidade e nível de complexidade. Esse tipo de fonte contém um discurso subjetivo que deve ser analisado minuciosamente. Nesse sentido, a produção de escrita de si por parte de políticos constitui um denso manancial para o estudo das representaçôes sobre política na Primeira República. A escrita de si ou o registro autobiográfico vem assumindo importância cada vez maior no contexto historiográfico recente, especialmente no campo de análise das representaçôes construídas por indivíduos na sua subjetividade, isto é, na forma como percebem e atribuem sentido à realidade vivida.

Para Ângela de Castro Gomes, o historiador, ao lidar com estes materiais, deveria se "municiar dos nada novos procedimentos de críticas às fontes, guarnecidos com escolhas teóricas e metodológicas capazes de filtrar o calor, de maneira a não ter a boca queimada". ${ }^{4}$ Neste sentido, alerta para o perigo da mera substituição das fontes oficiais pelo registro privado que poderia atestar com uma maior carga de subjetividade e veracidade as motivaçóes não expressas da ação do ator político.

A produção de escrita autorreferencial é algo igualmente recente que aparece no mundo moderno como uma prática de indivíduos comuns que passam a produzir uma memória de si. A autobiografia e a biografia, vinculadas a esse tipo de prática discursiva, surgiram primeiramente em países de língua inglesa a partir do século XVII. Como gênero literário, ambas se difundem por alguns países europeus ao longo do século XIX. Atravessam o oceano e, na América do Norte nascida sob o signo da modernidade, difunde-se com facilidade devido à extrema importância dada ao registro pessoal e à reminiscência como elemento de afirmação da individualidade.

O romance e a autobiografia podem ser considerados "gêmeos quase siameses", 5 pois a biografia pega emprestado do romance a narrativa adequada e os modelos de vida que pro-

\footnotetext{
${ }^{3}$ Natural de Macaé no estado do Rio de Janeiro, Washington Luís Pereira de Souza (1869-1957) iniciou carreira como advogado em Batatais, no interior paulista, vindo a ser eleito vereador e intendente municipal. Muda-se para a capital, sendo eleito deputado estadual em 1904. Ocupa a Secretaria da Justiça e Segurança Pública nos governos de Jorge Tibiriçá e Albuquerque Lins. Em 1914, com apoio do PRP, torna-se prefeito da capital paulista, reelegendo-se em 1916 com o apoio do governo de Altino Arantes, a quem sucede na presidência do estado em 1920.

${ }_{4}^{4}$ GOMES, Ângela de Castro. Nas malhas do feitiço: o historiador e os encantos dos Arquivos Privados. In: Estudos Históricos, Rio de Janeiro, v. 11, n. 21, p. 125, 1998.

${ }^{5}$ CALLIGARIS, Contardo. Verdades de autobiografias e diários íntimos. Estudos Históricos, Rio de Janeiro, v. 11, n. 21, p. 22-24, 1998.
} 
curam dar certa coerência aos eventos de toda uma vida. Assim, insere-se uma preocupação com a questâo da veracidade dos fatos à qual o registro autobiográfico parece corresponder. A noção de uma relação intrínseca entre subjetividade e verdade parece provir da concepção de que a autobiografia consistiria em um tipo de representação do sujeito, relação que Calligaris considera ingênua. ${ }^{6}$ Ele afasta a ideia de que o sujeito possua um conteúdo a ser representado, uma vez que se encontra numa condição de esvaziamento construída por ele mesmo ao recusar o próprio destino e/ou essência decididos pela tradição.

O sujeito estaria convencido de ser o autor de seu discurso, e não um mero espectador. Essa consciência do sujeito capaz de produzir a si próprio, da capacidade de conduzir seu próprio destino, transfere toda a sua força ao texto autobiográfico. Calligaris adota aqui a concepção formulada por Georges Gusdorf de "ato autobiográfico", definido como algo historicamente dado, uma vez que a autobiografia representaria ao mesmo tempo a saída de uma sociedade tradicional e o "sentimento de história como aventura autônoma, individual".

Os motivos pelos quais os indivíduos são levados, a partir da época moderna, a arquivar as próprias vidas, isto é, os processos de guarda de materiais ligados diretamente à escrita de si propriamente dita (autobiografias, diários, correspondência passiva) ou à constituição de uma memória de si (fotografias, cartóes-postais etc.), têm uma relação direta com certas pressôes sociais no sentido de mantermos nossas vidas organizadas. ${ }^{8}$ Nesse processo manipulamos a existência, rasuramos, riscamos, sublinhamos ou damos destaque a certas passagens de nossas vidas.

A tentativa do indivíduo de construir uma identidade para si por intermédio de seus documentos constitui então uma emergência histórica em contraste com as sociedades tradicionais que tendiam a se sobrepor aos interesses individuais, reprimindo sua manifestação. Porém, no contexto da sociedade moderna, o indivíduo desempenha uma série de papéis sociais sobrepostos e geralmente desarmônicos, que dificultam enfim a construção de uma identidade coesa, e nesse sentido a produção de si constitui uma forma de se proteger da fragmentação do eu, própria da vida moderna. No entanto, Bordieu contesta a ideia de historicidade do sujeito, e considera que seria falaciosa a afirmação de que uma vida é uma história, não sendo, portanto, crível a concepção de linearidade proposta pelo discurso biográfico. ${ }^{10}$ Giovanni Levi segue o argumento de Bordieu a respeito da "ilusão biográfica" devido à ausência de contexto, isto é, a "superfície social" em que age o indivíduo. ${ }^{11}$ Existiriam problemas relacionados à reconstrução do perfil biográfico, distorções provocadas pela ideia

\footnotetext{
${ }^{6}$ Ibid., p. 48-49.

${ }^{7}$ Ibid., p. $20-21$.

${ }^{8}$ ARTIÈRES, Philippe. Arquivar a própria vida. Estudos Históricos, Rio de Janeiro, v. 11, n. 21, p. 9-11, 1998.

${ }^{9}$ GOMES, Ângela de Castro. Nas malhas do feitiço, op. cit. p. 12.

${ }^{10}$ BORDIEU, Pierre. A ilusão biográfica. In: FERREIRA, Marieta de Moraes; AMADO, Janaína (Org.). Usos e abusos da história oral. 8. ed. Rio de Janeiro: Editora FGV, 2006. p. 183-191.

${ }^{11}$ LEVI, Giovanni. Usos da biografia. In: FERREIRA, Marieta de Moraes; AMADO, Janaína (Org.). Usose abusos da história oral, op. cit. p. 169.
} 
de que os "atores históricos" seguem um "modelo de racionalidade anacrônica e limitado", remetendo à ilusáo da personalidade coerente e estável.

Tais colocaçóes podem ser aplicadas à análise da autobiografia, como o questionamento em relação à identidade unitária do personagem da narrativa, isto é, a ilusão de coerência do indivíduo, e a necessidade de se buscar um meio-termo para resolver o impasse existente entre a ideia de liberdade de ação dos indivíduos e o determinismo social das estruturas.

Tomando como pressuposto essas consideraçôes, analisamos especificamente o diário íntimo de Altino Arantes, político paulista que no auge de sua carreira tomou a iniciativa de registrar de forma indelével sua experiência como governador de São Paulo. O diário encerra, de alguma maneira, certas pretensóes intelectuais e literárias do autor, além, é claro, da preocupaçáo, expressa no introito do primeiro volume, de resguardar sua imagem para a posteridade.

\section{Diários íntimos e diários políticos}

Algumas vezes o biografado, ao trabalhar com a memória de si, produz uma reflexão construindo um discurso seu a partir de discursos dos outros. Esse meta-arquivo se constitui em fragmentos autobiográficos diversos que expressam da parte do titular um desejo de construção de uma autoimagem. ${ }^{12}$ Entre estes materiais destaca-se o diário íntimo, jornal intime ou diary, um tipo de escrita autorreferente bastante singular identificado com a narrativa autobiográfica. Philippe Lejeune, em suas pesquisas relacionadas à autobiografia, dedicou-se ao estudo dos diários traçando-lhes alguns aspectos normativos envolvidos na sua análise. Insiste na concepção do diário como uma modalidade de escrita cotidiana, "uma série de vestígios datados", em geral manuscrito pela própria pessoa, em primeira pessoa, cujo conteúdo não poderá ser alterado, aspecto que reforça seu caráter individualizante e sua existência única. ${ }^{13}$ O diário serviria para construir ou exercer a memória de seu autor que se inscreve na duração; por esse motivo, fragmentação e repetição são traços invariáveis comuns.

No contexto brasileiro, o diário pessoal e a escrita íntima praticamente inexistiram, por longo período, como gênero literário. Para Gilberto Freyre faltaria motivação aos povos dos trópicos para o chamado "exame de consciência", feito em geral no confessionário do padre. Tal argumento de cunho religioso é rebatido por Cabral de Mello, que aponta para dois possíveis fatores explicativos: o baixo nível educacional que prevalece até as primeiras décadas

\footnotetext{
${ }^{12}$ FRAIZ, Priscila. A dimensão autobiográfica dos arquivos pessoais: o Arquivo de Gustavo Capanema. Estudos Históricos, Rio de Janeiro, v. 11, n. 21, p. 74-77, 1998.

${ }^{13}$ LEJEUNE, Phillipe. O pacto autobiográfico: de Rousseau à internet. Organização de Jovita Maria G. Noronha; tradução de Jovita Maria G. Noronha e Maria Inês C. Guedes. Belo Horizonte: UFMG, 2008, p. 260.
} 
do século XX, dificultando o exercício da escrita pessoal, e a ausência de uma "cultura da vida privada" nos países de colonizaçáo ibérica, ao contrário daqueles de cultura protestante que a desenvolvem precocemente. ${ }^{14}$

Maria Helena Machado aponta para aspectos análogos aos indicados por Cabral de Mello ao afirmar que a raridade desse tipo de fonte histórica se daria em uma sociedade "pouco afeita às letras em geral, e menos ainda à valorização do registro pessoal e da reflexão íntima" vindo "apenas tardiamente, em tempos mais modernos, via psicanálise (...), vulgarizar-se a escrita do diário". 15

A análise dessa autora recaiu justamente sobre o diário íntimo do general José Vieira Couto de Magalhães, personalidade do Segundo Império com participação ativa na vida pública brasileira. Machado procura empreender um estudo das mentalidades das elites da época que vivia a experiência da modernidade do capitalismo na segunda metade do século XIX. Ao esmiuçar os registros de Couto de Magalhães, a autora se defrontou com citaçóes e referências a selvas, a rios caudalosos e a sertóes infindáveis. Desenvolve, assim, uma crônica do cotidiano com o qual procura repassar sua vida para melhor compreendê-la e controlá-la.

Deduz-se disso a importância assumida pelos diários íntimos, algo que se torna mais contundente no caso de personalidades públicas, por envolver apreciaçóes privadas pouco comuns, ausentes mesmo na documentação epistolar do personagem. Desenvolve-se assim uma "imagem da vida interior", produto da meditação constante com o qual o indivíduo refaz sua própria biografia, para si mesmo e para os outros. ${ }^{16}$

$\mathrm{Na}$ verdade, poucos políticos brasileiros legaram à posteridade o registro na forma de diários. E muito pouco do que existe mereceu publicação integral e análise acadêmica. $\mathrm{O}$ diário de Getúlio Vargas é um desses exemplos raros, investigação que envolveu um extenso trabalho de transcrição dos manuscritos originais por pesquisadores da Fundação Getulio Vargas. Em sua apresentação, Celina do Amaral Peixoto ${ }^{17}$ classifica o diário de Vargas como estritamente "pessoal" por se tratar de um "guia para a própria vida".

O diário íntimo do político paulista Altino Arantes Marques se aproxima do estilo adotado por Vargas, por se caracterizar pela mistura ou entrelaçamento de situaçôes públicas com reminiscências íntimas e pessoais, sendo mais que um diário político. Seu autor não se limita a registrar os aspectos burocráticos de sua atividade cotidiana, mas se póe a formular opiniōes a respeito de seus subordinados e pares, expóe sentimento de perplexidade e dúvi-

\footnotetext{
${ }^{14}$ MELLO, Evaldo Cabral de. O fim das casas-grandes. In: NOVAIS, F. (coord.-geral), ALENCASTRO, Luiz Felipe (org. do volume). História da vida privada no Brasil: Império: a corte e a modernidade nacional. São Paulo: Companhia das Letras, 1998. v. 2, p. 386-388.

${ }^{15}$ MAGAlHÁES, José Vieira Couto de. Diário intimo. Organização de Maria Helena P. T. Machado. São Paulo: Companhia das Letras, 1998. p. 21.

${ }^{16}$ CALLIGARIS, Contardo. Verdades de autobiografias e diários íntimos, op. cit. p. 46.

${ }^{17}$ GETÚlIO Vargas: diário. Apresentação de Celina do Amaral Peixoto; edição de Leda Soares [Pesquisadores: Maria Celina D’Araujo, Regina Luz Moreira e Ângela de Castro Gomes]. São Paulo: Siciliano; Rio de Janeiro: Ed. Fundação Getulio Vargas, 1995. 2 v, p. VII-XIII.
} 
da a respeito de suas próprias atitudes, como o faz Vargas. A dimensão mais propriamente recôndita e íntima de sua vida pessoal é esmiuçada quando se refere à esposa recém-falecida, as dificuldades ao lidar com filhos adolescentes, nos preparativos de mudança para o Palácio presidencial, nas viagens para o balneário do Guarujá, idas ao teatro ou ao cinematógrafo, enfim, situaçóes nas quais afloram sentimentos absortos, devaneios e sonhos.

O manuscrito do diário se compóe de 15 cadernos. Cada caderno apresenta na contracapa o ex-libris do autor, na primeira página, a numeraçáo do volume demonstrando um esforço de organização, na seguinte, o título inicial Meu diário que abre a entrada cronológica inicial. ${ }^{18}$ Recobrindo exatamente o período do mandato de Altino como presidente do estado de Sáo Paulo (1916-1920), o conjunto desses registros cotidianos ininterruptos não enseja por parte do autor a organização de uma memória biográfica. Algum esforço autobiográfico apareceria no livro Passos do meu caminho, publicação que reuniu artigos e parte de sua produção intelectual. ${ }^{19}$

Ao contrário das reminiscências deixadas por Couto de Magalhães, as anotações de Altino se davam no calor dos eventos, das crises sucessivas que marcaram seu governo. Também dos acertos e acordos firmados com o círculo de poder, que incluía, além do seu secretariado, os membros da Comissão Central do Partido Republicano Paulista (PRP), do dia a dia despachando com coronéis locais e chefes regionais a resolver impasses políticos-eleitorais.

Em determinada passagem significativa de seu diário, Altino reexamina seus atos como gestor público e procura se escusar diante das críticas que pareciam lhe atormentar:

1o de Maio [1917] — Transcorre hoje o primeiro aniversário de meu governo. Devo ter errado muito, e certo; mas o que se me não poderá contentar jamais é que tenha trabalhado com dedicação e honradez por São Paulo, por seu bem-estar e por seu progresso. Tenho sofrido também muitas e clamorosas injustiças, na apreciaçáo de meus atos e até, de meus propósitos. Isto porém, pouco importa, quando se tem a consciência tranquila e olhos postos em Deus, em Deus que jamais me abandonou, nos transes mais angustiosos de minha vida e cuja indefectível proteção me conduzirá ao termo feliz de meu quatriênio. ${ }^{20}$

Apesar de reconhecer dificuldades na sua administração, ao reclamar dos ataques sofridos, Altino revela sua arrogância, pois parece convicto de estar seguindo o caminho correto, uma vez que seus atos se amparam na devoção divina. O que se percebe claramente nesse

\footnotetext{
${ }^{18}$ A cópia do manuscrito original do Diário intimo de Altino Arantes (intitulado Meu diário. Registro intimo de fatos e impressóes) encontra-se no acervo do Arquivo Público do Estado de São Paulo (Aesp), dividido em três lócus integrantes do Arquivo Privado Altino Arantes (Apaa), perfazendo cinco volumes encadernados. O primeiro compreende o período de 1-5-1916 a 31-10-1917 (Aesp. Apaa. Lócus: AP91.01.001), o segundo, de 1-11-1917 a 7-3-1919 (Aesp. Apaa. Lócus: AP92.01.001) e, por fim, o terceiro, de 8-3-1919 a 28-4-1920 (Aesp. Apaa. Lócus: AP93.01.001).

${ }^{19}$ MARQUES, Altino Arantes. Passos do meu caminho. Rio de Janeiro: José Olympio, 1958. 2 v.

${ }^{20}$ Arquivo do Estado de São Paulo (Aesp). Arquivo Privado Altino Arantes (Apaa). Locus: AP91.01.001. v. 4.
} 
trecho é o ressentimento de Altino em relação a seus detratores, especialmente a Júlio de Mesquita, líder dos dissidentes e chefe de $O$ Estado de S. Paulo, de onde partiam os artigos mais virulentos contra o governo paulista.

$\mathrm{Na}$ leitura de diversos outros trechos do diário, seu autor procura fazer justiça consigo mesmo, característica muito comum nas narrativas autobiográficas, reforçando a honradez e a fé católica, valores que acredita incorporar como homem público e que eram compartilhados pelos demais membros do grupo político do qual fazia parte.

O esboço do perfil biográfico de uma personalidade política deve se revestir de certas precauçôes no sentido de se evitar recair nos estereótipos construídos em torno do personagem. Sua rápida ascensão como político, uma vez que alcançou a presidência do estado antes dos quarenta anos de idade, seguiu de alguma maneira o cumprimento dos estágios requeridos para ingresso no restrito círculo da elite política confinada na Comissão Central do Partido Republicano Paulista (PRP), porta de entrada para os cargos administrativos do alto escalão da máquina burocrático-estatal paulista.

\section{Do interior paulista para a Belle Époque paulistana: a trajetória anterior ao diário}

Altino Arantes Marques nasceu em 29 de setembro de $1876^{21}$ em Batatais, na época um próspero município cafeeiro da Alta Mogiana ${ }^{22}$ (atual nordeste paulista). Filho do coronel Francisco de Arantes Marques, importante negociante de "fazendas, secos e molhados" na localidade. Cursou o ensino secundário no Colégio São Luís, na cidade de Itu, estabelecimento confessional dirigido por padres jesuítas. Essa influência religiosa colaborou certamente para reforçar valores e convicçóes morais, manifestos em diversos trechos do diário. Esse traço particular de seu comportamento, no entanto, náo o distinguia do perfil médio dos membros da elite política paulista, que possuíam uma visão mais cosmopolita, moldada nas viagens constantes pela Europa e na leitura de obras filosóficas que expressavam uma visão menos tradicional do mundo. ${ }^{23}$

Já instalado na capital, Altino frequentou a Faculdade de Direito do Largo do São Francisco, obtendo o grau de bacharel em 1895. Ali certamente entrou em contato com o ideário positivista professado num âmbito extraoficial na academia, que sustentara convicçóes políticas na primeira fase republicana. O PRP da fase da propaganda nas décadas de 1880 e 1890 incorporou lemas positivistas de viés modernizador, em especial a crença na possibilidade de organizar racionalmente a sociedade com base em princípios científicos expressos em teorias conexas com essa corrente - como o darwinismo social, o monismo alemão e o

\footnotetext{
${ }^{21}$ Faleceu em 5 de julho de 1965, na cidade de São Paulo.

${ }^{22}$ Refere-se ao trecho coberto pela antiga Companhia Mogiana de Estradas de Ferro.

${ }^{23}$ SEVCENKO, Nicolau. Literatura como missão: tensôes sociais e criação cultural na Primeira República.

2. ed. Prefácio de Francisco de Assis Barbosa. São Paulo: Brasiliense, 1985. p. 21.
} 
spencerianismo - que colaboraram para moldar as instituiçóes e a forma do Estado, pensados após a Proclamação da República. ${ }^{24}$

É provável que ideias poderosas como essas tenham inspirado jovens bacharéis como $\mathrm{Al}$ tino, pois ao retornar à sua terra natal iniciou-se na carreira jurídica, associando-se a uma figura de expressão na localidade, o forasteiro Washington Luís. Este se mudara para Batatais dois anos antes, a convite de um colega do tempo das arcadas, Joaquim Celidônio Gomes dos Reis Júnior. ${ }^{25}$ Advogado competente e carismático, Washington rapidamente ascendeu na carreira vindo a ser eleito vereador, levando consigo seu novo amigo Altino. Ambos fundaram e dirigiram, juntamente com Celidônio Jr., o jornal A Lei em 1897, um periódico em defesa da causa do municipalismo, além de colaborarem com artigos em outros como $O$ Direito, A Penna e A Justiça. ${ }^{26}$

Altino tentou ser eleito vereador em 1898, quando se envolveu em uma disputa eleitoral pelo comando da edilidade, encontrando-se em lado oposto ao de seu colega Washington que tentava se reeleger. ${ }^{27}$ Altino começava a desfrutar do prestígio de sua família, pois uma das principais lideranças políticas na cidade era seu tio, o coronel Eduardo Garcia de Oliveira, então deputado estadual. Ao organizar o diretório local do PRP, Oliveira colocou seu sobrinho como secretário. ${ }^{28}$

A derrota no pleito aparentemente não lhe deixou mágoas, pois seus comentários sob os tempos de "advogado na roça" demonstram que se tratava de um momento de sua juventude, de preparação para um neófito em assuntos políticos. ${ }^{29}$ Sem nunca ter ocupado cargo relevante na esfera local, acabaria anos mais tarde sendo indicado para disputar o cargo de deputado federal na chapa oficial do PRP na eleição de 1906. Tal feito se devia à significativa influência de sua tradicional parentela, reforçada pelos fortes laços mantidos com a família Junqueira, em especial com o coronel Joaquim da Cunha Diniz Junqueira, o "Quinzinho". ${ }^{30}$

\footnotetext{
${ }^{24}$ SANTOS, Wanderley Guilherme dos. Ordem burguesa e liberalismo político. São Paulo: Duas Cidades, 1978. p. 89.

${ }^{25}$ MARQUES, Altino Arantes. Washington Luís em Batatais. In: Washington Luis: homenagem do Instituto Histórico e Geográfico de São Paulo. São Paulo: s.n., 1957. p. 11; LOVE, Joseph. A locomotiva: São Paulo na federação brasileira Brasileira (1889-1937). Tradução de Vera Alice Cardoso da Silva. Rio de Janeiro: Paz e Terra, 1982. p. 406 e 408.

${ }^{26}$ Ibid., p. 16-8.

${ }^{27}$ Ibid., p. 9-31.

${ }^{28}$ DEBES, Célio. Washington Luis: primeira parte: 1869-1924. São Paulo: Imesp, 1994. p. 45.

${ }^{29}$ MARQUES, Altino Arantes. Washington Luís em Batatais, op. cit.

${ }^{30}$ Neste caso, a chefia distrital da regiáo de Ribeirão Preto, uma das mais ricas e importantes do estado, era garantida por Quinzinho, que influía na política estadual amparado também nas relaçóes amistosas que mantinha com Washington Luís. In: PAZIANI, Rodrigo Ribeiro. Construindo a Petit Paris: Joaquim Macedo Bittencourt e a Belle Époque em Ribeirão Preto (1911-1920). Tese (doutorado em história) — Faculdade de História, Direito e Serviço Social de Franca, Universidade Estadual Paulista "Júlio de Mesquita Filho", Franca, 2004.
} 
O vínculo com os Junqueira se iniciara desde seu primeiro casamento, ocorrido em 1899 na cidade de Franca, com Maria Teodora de Andrade Junqueira. ${ }^{31}$ Sua primeira esposa faleceu em São Paulo, em 12 de março de 1915, deixando-lhe órfăos seus dois filhos Stella e Paulo Francisco, perda intensamente lamentada ao longo do diário. No último ano de seu quatriênio presidencial, contrairia núpcias com Gabriela da Cunha Diniz Junqueira, filha de Quinzinho, em casamento realizado na capital em 24 de maio de 1919. Dessa união nasceram dois filhos: Maria Bernadete e Joaquim. Confirmava-se assim a extensão dos interesses políticos ao campo das relaçóes familiares.

Em sua estreia no Congresso Nacional, Altino começaria se destacando na defesa do famoso Acordo de Taubaté firmado entre os estados de São Paulo, Rio de Janeiro e Espírito Santo. Sua colaboração se daria mais especificamente na implementação da Caixa de Conversão, criada para estabilizar o câmbio e impedir sua valorização. $O$ governo federal acabaria apoiando tal instrumento por sua eficácia em manter a taxa cambial superior à do mercado livre, e assim atrair moeda estrangeira. ${ }^{32} \mathrm{O}$ êxito da Política de Valorização do Café se prolongaria até as vésperas da Primeira Guerra Mundial, cessando as crises frequentes no setor.

$\mathrm{Na}$ esteira do sucesso, Altino seria reconduzido em 1909 para mais um triênio. No entanto, em novembro de 1911 renunciou ao mandato para assumir a Secretaria de Negócios do Interior a convite do então presidente paulista Albuquerque Lins (1908-1912). A razão de sua decisão é que a pasta detinha a maior fatia do orçamento, conferindo ao ocupante um enorme poder de barganha e controle dos processos eleitorais. Altino certamente avaliou que tal posição o colocava em condição de vantagem política, ao adquirir um tipo de experiência que ainda não possuía, e que certamente faria a diferença se estivesse interessado em alçar voos mais ambiciosos.

Interessante notar que Altino tinha como colega de gabinete seu amigo dos tempos de Batatais, Washington Luís. Este comandava a Secretária da Justiça e Segurança Pública desde o governo de Jorge Tibiriçá, e vinha se destacando no processo de reforma da polícia e do Judiciário estadual, ocupando-se da modernização da Força Pública treinada por uma missão de oficiais do exército francês. Washington ocupou por curto período uma vaga no legislativo estadual, tornando-se um administrador experimentado, elogiado por seus pares no PRP.

Ao contrário de seu colega, Altino parecia se encontrar em situação mais favorável. Ao montar seu secretariado, o recém-eleito conselheiro Rodrigues Alves (1912-1916) manteve Altino na mesma pasta. Com o tempo ele se tornaria um dos mais fiéis defensores do político de Guaratinguetá, ${ }^{33}$ fato que se revelaria auspicioso para sua ascensão política. ${ }^{34}$

\footnotetext{
${ }^{31}$ Consta uma referência ao pedido de casamento que teria sido feito em 15 de agosto de 1899. In: Aesp. Apaa. Lócus: AP92.01.001. v. 6 [15-8-1917].

${ }^{32}$ MELLO, João Manuel Cardoso de. O capitalismo tardio: contribuição à revisão crítica da formação e do desenvolvimento da economia brasileira. São Paulo: Brasiliense, 1982. p. 138-139.

${ }^{33}$ EGAS, Eugênio. Galeria dos presidentes do estado de São Paulo e vice-presidentes. v. 2 (Período republicano 1889-1920). São Paulo: Seção de obras d' “O Estado de S. Paulo”, 1927. p. 481.

${ }^{34}$ FRANCO, Afonso Arinos de Melo. Rodrigues Alves: apogeu e declínio do presidencialismo. Prefácio de
} 
A eleição do conselheiro fortaleceu as posiçôes de seu grupo no plano estadual e serviu para superar a crise institucional, afastando qualquer possibilidade de intervençáo federal, devido ao apoio paulista a Rui Barbosa nas eleiçóes presidenciais de 1910 e às ambiçóes do senador gaúcho Pinheiro Machado, que desejava controlar a situação política em São Paulo e Minas Gerais. ${ }^{35}$ Machado colocou à testa do diretório paulista do Partido Republicano Conservador (PRC) Rodolfo Miranda, o mesmo que comandara a pró-hermista Junta Republicana, juntamente com Campos Sales e Francisco Glicério. ${ }^{36}$ Em fins de 1911, Miranda teria plantado uma denúncia na imprensa envolvendo a posse pelo governo paulista de armamento de uso exclusivo do Exército e insuflado uma rebeliâo na Força Pública com o apoio do major Assis Brasil. O governador Albuquerque Lins apressou-se nos preparativos para um eventual ataque das tropas federais, contando com seus secretários mais próximos, Altino Arantes e Washington Luís. ${ }^{37}$

A escolha de Rodrigues Alves resultou, portanto, de um acordo firmado entre as facçóes internas do PRP para unificar a política paulista e evitar a intervenção. O PRC paulista que lançou Miranda como candidato oficial à presidência do estado desistiu desse intento, obtendo em troca representatividade na legislatura federal e depois assento na Comissáo Central do PRP. ${ }^{38} \mathrm{O}$ conselheiro teve o apoio de centros hermistas como o de Ribeirão Preto comandado pelo coronel Quinzinho Junqueira, que viria a ser depois sogro de Altino Arantes.

Eleito, o conselheiro passa a se dedicar à questáo da sucessão federal que se tornara problemática com a possibilidade da candidatura de Pinheiro Machado. Rodrigues Alves aceita o convite de Bias Fortes do Partido Republicano Mineiro (PRM), para constituição de um pacto interestadual contra o PRC, firmado em março de 1913, do qual resulta a formação no Congresso do agrupamento denominado Coligação, que irá impugnar a candidatura de Machado. O PRM aventa a candidatura de um de seus líderes, o vice-presidente da República Wenceslau Braz, que acabaria sendo aceita por todos os partidos situacionistas. Aproveitando a oportunidade, Pinheiro Machado lidera uma convenção do PRC e coligados que lança oficialmente a chapa Wenceslau e Urbano dos Santos. Essa manobra mantém Macha-

Francisco de Assis Barbosa. Rio de Janeiro: José Olympio; São Paulo: Editora da Universidade de São Paulo, 1973. v. 2, p. 607.

${ }^{35}$ Líder incontestável do situacionismo gaúcho até sua morte em 1915, Pinheiro Machado pode ser considerado um dos pilares da política federal, juntamente com o PRP e o PRM. O crescimento de seu poder se deu durante a instalação da política dos governadores, quando passou a controlar a Comissão de Verificação de Poderes do Congresso devido a seu prestígio no Senado. Estabeleceu ligaçóes vantajosas com vários grupos políticos dos estados do Norte e do Nordeste, tendo em suas mãos suas bancadas federais. SOUZA, Maria do Carmo Campello de. O processo político-partidário na Primeira República. In: MOTA, Carlos Guilherme. Brasil em perspectiva. 6. ed. São Paulo; Rio de Janeiro: Difel, 1975. p. 188-189.

${ }^{36}$ DEBES, Célio. Washington Luis, op. cit. p. 109-111.

${ }^{37}$ FRANCO, Afonso Arinos de Melo. Rodrigues Alves, op. cit. v. 2, p. 607.

${ }^{38}$ CASALECCHI, José Ênio. O Partido republicano paulista: política e poder (1889-1926). São Paulo: Brasiliense, 1987. p. 139-140. 
do como importante protagonista na política nacional por curto período, pois o novo presidente rejeita a submissão aos ditames do PRC, o que na prática levaria à sua decomposição. ${ }^{39}$

Superada essa crise em nível federal, o conselheiro Rodrigues Alves teria pouco tempo para comemorar, pois passa a se ocupar da condução de sua sucessão no governo estadual. As manobras pré-eleitorais custariam toda unidade partidária construída anteriormente, provocando uma grave crise no PRP, tendo Altino Arantes no epicentro do debate em fins de 1915.

Todo este imbróglio teve início com a indicação da chapa oficial à sucessão do conselheiro, encabeçada por João Álvares Rubião Jr., presidente do Senado Estadual, tendo como vice Altino Arantes. A oposição liderada por Jorge Tibiriçá e Bernardino de Campos tentou lançar, sem êxito, a candidatura de Fernando Prestes.

Inesperadamente Rubiáo Jr. veio a falecer provocando a realização de uma Convenção partidária a 7 de novembro para escolher outra chapa. Os dissidentes rapidamente indicaram o nome de José Cardoso de Almeida, secretário da Fazenda (Cincinato Braga também fora cogitado), algo que provocou profundo desagrado ao conselheiro. Este resolveu bancar a candidatura de Altino Arantes, enviando uma carta pública ao chefe da presidente da Comissão Executiva do PRP Jorge Tibiriçá. ${ }^{40}$ Ao que parece, Altino alçara à condição de discípulo fiel e confrável, como deixa entrever o comentário de Casalecchi:

(...) conhecido como o mais palaciano dos secretários, amigo pessoal dos filhos do presidente do Estado, em especial de Oscar Rodrigues Alves, cogitando-se mesmo na ação deles para aquela indicação, Altino Arantes tem a candidatura combatida com fervor pelos dissidentes. ${ }^{41}$

A perspectiva de chegar antes dos quarenta anos à presidência do Estado "não poderia deixar de acender invejas e suscitar restriçóes”; conforme assinala Melo Franco, mereceu glosa desagradável: "Até mesmo do prestígio que lhe conferia a presidência, seu nome, não chegou a se impor nacionalmente, como vemos pelos sarcasmos de Rui, quando se refere ao futuro presidente paulista como sendo 'a menina do piano". ${ }^{42}$

A dissidência atacou intensamente a candidatura veiculando críticas por meio do jornal O Estado de S. Paulo. Júlio de Mesquita, chefe desse periódico, assume a representação dos dissidentes às vésperas da Convenção que foi presidida por Francisco Glicério, que teve

\footnotetext{
${ }^{39}$ SOUZA, Maria do Carmo Campello de. O processo político-partidário na Primeira República, op. cit. p. 209-212.

${ }^{40}$ Rodrigues Alves pensou em indicar Altino primeiramente para ministro da Justiça de Wenceslau Braz. Cf. FRANCO, Afonso Arinos de Melo. Rodrigues Alves, op. cit. p. 775.

${ }^{41}$ CASALECCHI, José Ênio. O Partido republicano paulista, op. cit. p. 147-148.

${ }^{42}$ FRANCO, Afonso Arinos de Melo. Rodrigues Alves, op. cit. p. 774. Este mesmo autor compara a trajetória de rápida ascensão de Altino à de um outro político da mesma época, David Campista, o que "não lhe permitiu o amadurecimento político necessário (náo confundamos isso com o amadurecimento pessoal) para que seu prestígio se impusesse realmente no meio federal, como, ao contrário, ocorreu com outro homem da sua geração, Washington Luís".
} 
início com o requerimento de Adolfo Gordo pedindo adiamento da decisão por quinze dias a fim de ganhar tempo para escolha de nome que reunisse os "sufrágios gerais". A maioria se opôs a essa medida, e após longo discurso de Carlos de Campos em nome da conciliação, buscando isentar o governo e referendar Altino, o requerimento de Adolfo foi rejeitado. Retiraram-se dezessete convencionais, e aqueles que ocupavam cargos no governo abandonaram suas posiçôes (João Sampaio, Paulo de Moraes Barros, Rafael Sampaio Vidal, Guimarães Júnior, Antônio Mercado, Antônio de Moraes Barros, Adolfo Gordo e Cesário Bastos). Abria-se, assim, uma nova cisão na política paulista.

Eleito, Altino Arantes sofreria durante seu mandato com o "antagonismo dos dissidentes", destacando-se a campanha contra a candidatura do cônego Valois de Castro para senador, o ataque à direçáo do PRP, por negar apoio a Rui Barbosa, ficando com Epitácio Pessoa na campanha sucessória de 1919, e o apoio aos movimentos paredistas de operários de 1917 e 1919, episódio que seria explorado pelo governo para enfraquecer a dissidência. ${ }^{43}$

Os cronistas de época apontaram para os flagelos que se abateram sobre os paulistas durante o curso do governo de Altino: a gripe, a geada, os gafanhotos, a guerra e, por fim, as greves, criando a expressão "cinco Gêe" para designar uma "conjuntura particularmente catastrófica" " ${ }^{44}$ Sua administraçáo teve de enfrentar muito mais que a oposição de parte de seu partido e a desconfiança dos chefes, pois certamente a crise no setor cafeeiro e a gravidade da "questão social" cobrariam um preço alto. ${ }^{45}$

\section{Registros privados de uma vida pública: as faces de Altino Arantes}

A administração de Altino teve início em meio a inúmeras dificuldades de ordem política. Sua legitimidade como candidato e inclusive sua capacidade para ocupar uma posição de destaque vinham sendo questionadas através da imprensa, colocando em risco a governabilidade.

Tornou-se objetivo fundamental, no primeiro momento, a busca de apoio para garantir um mínimo de estabilidade política. Estas condiçôes surgiram no vácuo criado pela debandada das lideranças dissidentes, pois uma série de cargos encontrava-se à disposição para livre negociação com possíveis aliados. No seu conjunto, favores e concessóes para serviços rendosos seriam distribuídos conforme a lógica prevalente do compromisso eleitoral, da manutenção da maioria nas duas casas do Congresso Estadual. O peso da máquina burocrática

\footnotetext{
${ }^{43}$ CASALECCHI, José Ênio. O Partido republicano paulista, op. cit. p. 149-150.

${ }^{44}$ SEVCENKO, Nicolau. Orfeu extático na metrópole. São Paulo: sociedade e cultura nos frementes anos 20. São Paulo: Companhia das Letras, 1992. p. 24.

${ }^{45}$ DOIN, José Evaldo de Mello. Capitalismo bucaneiro: dívida externa, materialidade e cultura na saga do café. Tese (livre-docência) — Faculdade de História, Direito e Serviço Social, Universidade Estadual Paulista “Júlio de Mesquita Filho", Franca, 2001. v. 1.
} 
estatal, reforçado pela centralização no Poder Executivo nesta primeira fase republicana, implicava uma situação de ostracismo dos dissidentes.

Um dos efeitos decorrentes desse processo foi alçar a postos relevantes antigas lideranças hermistas, tais como Rodolfo Miranda, Herculano de Freitas, Rafael Sampaio Vidal e o coronel Quinzinho Junqueira. A Comissão Executiva do PRP foi ampliada em 1913 devido à ameaça representada pelo PRC, como parte de um acordo com o presidente Hermes da Fonseca. ${ }^{46}$ Em 1916 novos membros foram incorporados, como o ex-dissidente Rodolfo Miranda, em meio a uma reformulaçáo conduzida por Rodrigues Alves que introduziu novidades como o mandato de quatro anos para coincidir com o período do governo. A estratégia adotada pelo conselheiro procurava assegurar uma comissão mais afinada com seu sucessor, em decorrência da disputa que se seguiu à convenção de $1915 .{ }^{47}$

Em meio a tantos dissabores que ocupavam diuturnamente a atenção de Altino, é curioso que ainda lhe restasse algum tempo para se ocupar do registro diário do exaustivo cotidiano palaciano e de suas atividades como homem público. A motivação para sua escrita tinha outros propósitos como instrumento para reafirmação de sua identidade, conferindo aos seus atos uma autoridade e uma legitimidade que pareciam escapar-lhe na vida real.

$\mathrm{Na}$ abertura do primeiro volume, ele redigiu uma breve nota no qual frisa o caráter privado do manuscrito:

Este caderno de notas íntimas é absolutamente reservado. Destina-se, como tantos outros que o precederam - desde os longínquos tempos do colégio de Itú, - à destruição pelo fogo purificador, no periódico auto de fé das caixas velhas e imprestáveis. Um só deles guardo ainda, no meu cofre, junto das modestas joias da minha querida morta. ${ }^{48}$ Não o consumi porque foi escrito expressamente para ela, durante os dias de sua última viagem ao interior. Intitulei-o, por isso, numa dolorosa antevisão do meu destino, "Soledade". E foi ela própria que - terminada a sua leitura, ainda em casa do [Bié] em Batatais, disse-me, sorridente e quase vaidosa: "É o mais precioso presente, que tenho recebido de tuas mãos; não o rasgarei, como pedis; guardá-lo-ei, sim, entre as minhas joias". Estou, pois, cumprindo neste particular um voto da Maria...

Se alguém, entretanto, der por qualquer forma, publicidade a ele ou a este caderno e aos que a ele seguirem, em todo ou em parte, — terá traído o meu pensamento e contrariado formalmente a minha vontade, que, neste caso aqui ficará para sempre consignada como um protesto...

\footnotetext{
${ }^{46}$ VISCARDI, Cláudia Maria Ribeiro. O teatro das oligarquias: uma revisão da "política do café com leite". Belo Horizonte: Fino Traço Editora, 2012.

${ }^{47}$ LOVE, Joseph. A locomotiva, op. cit. p. 162-164.

${ }^{48}$ Altino refere-se aqui à sua primeira esposa, Maria Theodora Andrade Junqueira Arantes, falecida em 12 de março de 1915, na cidade de São Paulo.
} 
Ao Paulo e a Stella ${ }^{49}$ incumbe neles pela execução fiel de minhas disposições. ${ }^{50}$

Neste breve trecho revela que mantinha o hábito de escrever diários desde sua adolescência, e que guardara em especial um caderno que se relacionava com a esposa falecida antes de sua posse na presidência do estado. ${ }^{51}$ Aliás, abundam as reminiscências que têm como mote sua esposa, constituindo um dos temas mais constantes nos seus registros a rivalizar com assuntos ligados aos problemas administrativos e à política em geral.

$\mathrm{O}$ argumento de Altino de que o conteúdo do diário náo constitui matéria passível de publicidade, por constituir-se em registros de interesse estritamente privado, parece não condizer com a própria natureza do "ato autobiográfico". 52 Pois a intenção subjacente do autor de textos autorreferentes seria a de ficcionalizar sua própria vida com o objetivo de construir uma imagem mais apropriada de sua personalidade. Um político como Altino valia-se, portanto, da suposta sinceridade da escrita de si, com todo seu efeito de veracidade náo comprometida necessariamente com a verdade factual, para manifestar sem as interdiçôes próprias das relaçóes sociais avaliaçóes acerca de seus atos como administrador público (foco do diário) ou sobre outrem.

\section{Construindo uma imagem de si: desejos e dificuldades}

Ao compor sua imagem, Altino procura em seu texto caracterizar-se ao mesmo tempo como um homem devoto e como um político honesto. Isto fica perceptível na descrição de sua posse como presidente de estado, momento no qual parece imbuído de sentimentos contraditórios ao manifestar surpresa e embevecimento diante do poder que lhe era conferido naquele instante, enquanto se ressentia da ausência da esposa no momento mais importante de sua vida:

Mas quanto me dói que à inesquecível companheira dos melhores quinze anos da minha existência, que a minha fiel e doce Maria náo esteja ao meu lado para compartilhar do meu triunfo! Ela, que só pensava e sentia através do meu sentir e do meu pensar! Ela que exultava nas minhas alegrias e chorava nos meus pesares! Ela que, mais que ninguém, confiava na minha capacidade e antevia os sucessos de minha carreira! Ela, a encantadora visionaria que ao passar comigo diante do Palácio dos Campos Elíseos - murmurava, embevecida, aos meus ouvidos, num carinhoso sorriso de invencível confiança: nossa casa! ... ${ }^{53}$

\footnotetext{
${ }^{49}$ Filhos de Altino Arantes do primeiro casamento.

${ }^{50}$ Aesp. Apaa. Lócus: AP91.01.001. v. 1 [Preliminar].

${ }^{51}$ Nossa análise se restringiu ao seu diário de governo, único conhecido até o momento, inexistindo informações mais completas acerca do conteúdo dos diários da adolescência.

${ }^{52}$ CALLIGARIS, Contardo. Verdades de autobiografias e diários íntimos, op. cit.

53 Aesp. Apaa. Lócus: AP91.01.001. v. 1 [1ํ-5-1916].
} 
Em situaçóes festivas e tristes, nas viagens para o interior paulista ou nas longas estadas em balneários, permanece latente a lembrança de Maria Theodora como um sentimento de culpa, como na descrição que faz de um sonho que parece tê-lo perturbado, por seu conteúdo mais ou menos erótico, durante breve passagem pelo Guarujá, feita em junho de 1916:

É meia noite, recolho-me. Acorda-me do primeiro sono [de] um pesadelo angustioso: alguém se insinuava devagarinho na cama e se acomodava mansamente a meu lado: era ela, a Maria a obsessão constante de minha saudade. Por mais que me esforçasse por enxergar-lhe as feiçóes, não o conseguiria, enquanto que ela, a seu termo, lutando debalde por falar-me, expelia apenas do peito, ofegante sobre o meu, uns sopros guturais, insonoros, frios, que me regulavam as fases $(. ..) .^{54}$

Altino apresenta por vezes uma tendência mórbida constante, pelo menos nos trechos do diário no qual se refere à esposa. O apelo para os sentimentos de forte fervor católico, as constantes idas ao cemitério, o comparecimento às missas dominicais, a participação em rituais religiosos, rezas, a mortificação constante, a vivência do luto. Em visita às obras de feitura do túmulo de sua esposa e, em seguida, a viagem empreendida para um santuário religioso ilustram esta devoção constante:

O túmulo da Maria está hoje quase pronto: o serviço de cantaria está concluído, faltando agora a estátua e o medalhão. Fui vê-lo e depositar flores sobre ele, antes de minha partida para a Aparecida onde vou — como nos anos anteriores — passar o meu já agora e sempre triste aniversário... Que encanto poderá ter para mim essa data, quando com a Maria desapareceu toda a poesia, todo o estimulo da vida?....

29 de Setembro [1916] — dia de meu 40ำ aniversário. Amanheço na Aparecida, onde segundo o costume que não quis quebrar - confessei e comunguei, implorando o auxílio de Deus e da Virgem para esta segunda fase de minha vida e a velhice. Sinto-me triste até às lágrimas, ao pensar na ausência da Maria, a única criatura, talvez, que se sentia contente e feliz em festejar o meu aniversário. Com quantos carinhos saía ela, nesses dias, manifestarme a sua incomparável afeição!... Hoje que já não há a possível, apavora-me a ideia de que a minha vida ainda se possa prolongar um igual número de anos! É uma perspectiva que me não seduz; desejo morrer o mais cedo possível, na paz e na segurança de minha Fé. Tal a graça que diariamente peço à Maria em minha Oração. Vivi 40 anos; 40 anos frios e estéreis, dos quais só me despertam saudades — fundas e doídas — os quinze que à Maria [enflorou] com a sua graça e povoou com a sua bondade e a sua ternura! ${ }^{55}$

\footnotetext{
${ }^{54}$ Aesp. Apaa. Lócus: AP91.01.001. v. 1 [25-6-1916].

${ }^{55}$ Aesp. Apaa. Lócus: AP91.01.001. v. 1 [28 e 29-6-1916].
} 
A ressentida ausência da esposa amada repercutia na dificuldade de lidar com os filhos adolescentes, como transparece em várias passagens de sua narrativa. Altino dedica sua atenção a seu filho mais velho, Paulo Arantes, um rapaz com pouco mais de dezesseis anos de idade. Em janeiro de 1917, quando Paulo estava se submetendo às avaliaçôes finais no Ginásio do Estado, surgiu uma polêmica em torno da composição das bancas examinadoras que teriam sido montadas para protegê-lo. Altino teria ficado apreensivo com os comentários, temendo o uso político desta informação pela oposição:

Este votou a formação das bancas, duplicadas, em que o Paulo foi examinado, comparecendo, entretanto, às provas do menino e felicitando-o até pelo brilho das de História Natural. Nessa matéria, foi ele aprovado com distinção e em Física e Química — plenamente grau 9, a melhor nota do dia (...). Posso, ao menos, ter essa consolação de verificar que meu filho não pretendia favores especiais: queria apenas que o tratassem como ao filho de qualquer outro mortal, tão bom ou tão mau como eu (...). Mas assim não convinha aos forjadores de escândalos e sobretudo aos espíritos acanhados e mesquinhos, que entendem que, para dar arras de sua independência, devem negar justiça aos que ocupam posição superior à deles (...)..$^{56}$

Muito mais grave parece ter sido o caso do envolvimento amoroso de Paulo com a enteada do ajudante de ordens, major Lejunne, fato que resultaria no pedido de exoneraçáo deste último, em vista do possível escândalo diante de algo que atentava contra o código moral vigente:

Comuniquei, então, ao Paulo - em meu quarto - o pedido de demissão do Major e a aquiescência, que eu acabava de lhe dar. $\mathrm{O}$ menino escutou-me entre lágrimas, a lamentarse da leviandade, em que incorrera e que - dizia ele, soluçante, — vinha recair sobre um inocente, de quem fora sempre amigo. Aproveitei-me do ensejo para uma oportuna lição de correção de conduta e consolei-o do melhor modo que pude (......57

Apesar das preocupaçóes, Altino se felicitava no mesmo dia com a aprovaçáo de Paulo na Faculdade de Direito, fato que atenuava em princípio o melancólico episódio. Em determinado registro aparece Paulo a se queixar amargamente dos "excessivos rigores" e recriminações de seu pai, e "da falta de carinhos paternais, que não eram regateados à Stelinha". ${ }^{58}$ A relação com a filha era consideravelmente diferente por causa da ausência da mãe, de maneira que certos tipos de preocupaçóes mereciam destaque velado:

\footnotetext{
${ }^{56}$ Aesp. Apaa. Lócus: AP91.01.001. v. 3 [22-1-1917].

${ }^{57}$ Aesp. Apaa. Lócus: AP91.01.001. v. 3 [29-3-1917].

${ }^{58}$ Aesp. Apaa. Lócus: AP91.01.001. v. 4 [29-7-1916].
} 
Acordei-me, às oito horas, para ouvir de D. Mariquinhas a notícia - que muito me interessou - de estar a minha querida Stella passando hoje pela sua primeira crise fisiológica! Pobrezinha! Não ter, nesse passo melindroso de sua vida, a assistência, o carinho e os conselhos da Mãe incomparavelmente, meiga e amorosa, que era a sua! (...). Com que pungente emoção eu a beijei, instantes depois, quando - com os ingênuos olhos vermelhos de chorar - veio pedirme a benção e abraçar-me! Que Deus te proteja, pobre órfă! (...). Que a Maria, lá do céu, onde para sempre descansa vele por ti, filha querida do nosso amor! (... $)^{59}$

Em decorrência de tais dificuldades e dos encargos da função pública que ocupava, Altino tratou rapidamente de contratar uma preceptora inglesa, ${ }^{60}$ prática comum entre as famílias de elite. Pauline Mary Purcell assumiu suas funçóes, e pelo menos durante certo tempo estabeleceu um clima de tranquilidade apenas perturbado pelo conflito doméstico que se estabeleceu entre a sogra e a governanta, a ponto de causar certa inquietação em Altino:

Duas personalidades, hoje indispensáveis no organismo manco de minha vida, que amiúde se chocam na disputa das mesmas atribuiçóes junto da minha pobre filha, esquecidas ambas de que, ao fim de contas, sobre mim e ela é que vem recair a ação triturante dos reiterados atritos! (...). Que infeliz condição a do viúvo com filhos menores! ${ }^{61}$

Interessante notar o desvelo e a dedicação de Altino para com seus filhos, que parece se estender para a memória de sua falecida esposa. Em relação aos primeiros, seguiu a atitude mais comum entre as famílias da elite paulista, a contratação de governanta para auxiliar na educação de sua filha, que poderia prosseguir seus estudos secundários na Escola Normal. Se as oportunidades eram escassas para o gênero feminino, abriam-se enormes possibilidades para moços como Paulo Arantes, que resolveu cursar direito no Largo do São Francisco. Love assinala que "era muito comum a elite enviar seus filhos para fazerem a faculdade no exterior”. ${ }^{62}$ Talvez Altino não possuísse recursos suficientes para tal intento, pois havia outras instituições que ofereciam uma formação compatível, como a Escola Politécnica (1895), a recém-instalada Faculdade de Medicina (1913), o Instituto Agrícola de Piracicaba (1901), além das possibilidades apresentadas pela capital federal. Essas instituições reforçavam a congregação e socialização da elite, forjando os quadros administrativos e políticos que iriam ocupar postos de comando durante a Primeira República. ${ }^{63}$

\footnotetext{
${ }^{59}$ Aesp. Apaa. Lócus: AP91.01.001. v. 4 [25-7-1916]. Provavelmente está fazendo referência à menarca ou primeiro fluxo menstrual de sua filha.

${ }^{60}$ Aesp. Apaa. Lócus: AP91.01.001. v. 2 [4-8-1916].

${ }^{61}$ Aesp. Apaa. Lócus: AP91.01.001. v. 5 [30-8-1917]. Em diversos trechos Altino revela a dificuldade de criar seus filhos na ausência da esposa.

${ }^{62}$ LOVE, Joseph. A locomotiva, op. cit. p. 124 e 146.

${ }^{63}$ NEEDELL, Jeffrey D. Belle Époque tropical. Sociedade e cultura de elite no Rio de Janeiro na virada do século. Tradução de Celso Nogueira. São Paulo: Companhia das Letras, 1993. p. 80.
} 
Altino era frequentemente instado por seus pares a se casar novamente, pois a condição de viúvo poderia despertar comentários maledicentes por parte de seus detratores. Cardoso de Almeida, seu secretário da Fazenda, em conversa reservada, sugeria a conveniência de que se casasse "o mais rápido possível", indicando-lhe até mesmo uma "noiva ideal" ${ }^{64}$ As pressóes acabariam demorando um pouco para surtir o efeito desejado, uma vez que Altino contraiu núpcias apenas no último ano de seu mandato. ${ }^{65}$

A autoimagem de cristão devoto que interpretava sua vida como imbuída de missão e sacrifício aparece no diário como um elemento retórico favorável e compatível com o universo de valores de seu grupo social. Como homem público, ajustou-se às práticas comuns ao período influindo no livre jogo do favor que constituía uma forma operativa comum, o mesmo podia valer no plano das relaçóes privadas no qual o coronel reafirmava seu poder frequentando os espaços da vida mundana da capital.

São muito sutis os trechos do diário no qual aparecem revelaçốes desse tipo. Em raro trecho no quarto volume, Altino parece confessar a suposta existência de um affair, que da maneira como é descrito se aproxima da admissão de um "deslize", uma pequena aventura do período de sua estada na capital federal:

Entre outras visitas, tive a da Judith F (...), meu antigo — e porque não confessá-lo? — saudoso conhecimento dos bons tempos do Rio (...). Não foi sem alguma comoção que a revi, quase dez anos decorridos após o nosso último encontro. É ainda uma bela mulher: mas a ação dos anos e dos sofrimentos - disse-o ela própria — já se faz tristemente evidente no seu rosto e no seu porte, outrora tão esbelto e tão senhoril! ${ }^{66}$

Esta única concessão no relato demonstra como este "caso" foi algo significativo na sua vida, a ponto de ainda causar-lhe perturbação aquele último reencontro:

(...) e, ao proferir estas palavras textuais, encarava-me fixamente, mostrando-me no brilho inalterado dos lindos olhos negros e fundos, os últimos esplendores de uma formosura, que me fascinara algum tempo e que tantas angústias causou à minha pobre Maria (...). Esta já não existe mais — ai de mim! —; viva que fosse, porém, não me dissuadiria, com certeza, de atender agora à modesta súplica da outra (..... ${ }^{67}$

\footnotetext{
${ }^{64}$ Aesp. Apaa. Lócus: AP91.01.001. v. 4 [10-5-1917].

${ }^{65}$ Aesp. Apaa. Lócus: AP93.01.001. v. 12 [24-5-1919].

${ }^{66}$ Aesp. Apaa. Lócus: AP91.01.001. v. 4 [23-7-1917].

${ }^{67}$ Ibid.
} 


\section{O círculo palaciano: conflitos no interior da oligarquia paulista}

Em sua narrativa, Altino procura construir a imagem de homem público, imbuído de um sentimento de dever, inclusive, ao interpretar sua ascensão política, a considera menos resultante de suas ligaçóes políticas e mais uma obra do acaso, como se decorresse de um suposto destino que lhe aguardava. Percebe-se esse aspecto no anúncio das normas que devem conduzir seu governo durante a primeira reuniáo com o secretariado. De início, revela sua intenção de harmonizar os conflitos internos no seio do partido:

Politicamente quero que sejam atendidos, no que for possível, todos dos chefes do Partido, sem preferências e sem preteriçóes odiosas, sem [preocupação] de correntes ou de grupos, visto como tenho o máximo empenho em tornar o P.R.P., de fato e de direito uma organização homogênea e coesa, em que se harmonizem e se fundam as aspiraçóes e os interesses de todos os bons republicanos. ${ }^{68}$

Havia, é claro, uma distância enorme entre este desejo de reconciliação política com o grupo dissidente e sua efetivação prática. Altino compusera seu gabinete com figuras de proa do "alvismo": Oscar Rodrigues Alves, na Secretaria do Interior; Cardoso de Almeida, na Fazenda; Elói Chaves, na Segurança Pública; e Cândido Rodrigues, na Agricultura. Este concerto mantinha o controle político-administrativo do estado sob a égide do grupo de Rodrigues Alves. Ataques ao governo poderiam ser atenuados mediante o atendimento das demandas dos diretórios locais, apaziguando os conflitos, distribuindo a chefia aos seus próceres, utilizando-se da máquina administrativa a cargo do Poder Executivo para convencer os oposicionistas do retorno às hostes partidárias. Como as divergências se mantinham menos no campo ideológico do que na esfera dos interesses de ocasião, os dissidentes acabariam se convencendo da situação inoportuna de manter-se alijados do partido, único meio de acesso aos cargos públicos e inumeráveis favores oferecidos pela máquina administrativa estatal, visto a simbiose entre o PRP e a cúpula do governo. ${ }^{69}$

Em seguida à conclamação de apaziguamento político, Altino avança em aspectos que considerava centrais para orientação da açáo de seu governo:

Administrativamente, quero a execuçáo inescrupulosa e integral da minha plataforma, especialmente no quis respeito à economia dos dinheiros públicos. Recomendo a redução das despesas à cifra exata das respectivas consignaçôes orçamentárias, sendo estas repartidas em

\footnotetext{
${ }^{68}$ Aesp. Apaa. Lócus: AP91.01.001. v. 1 [2-5-1916].

${ }^{69}$ PERISSINOTTO, Renato Monseff. Estado e capital cafeeiro em São Paulo (1889-1930). Prefácio de Décio Saes. São Paulo: Annablume/FAPESP, 1999. t. I. Especialmente o capítulo XI — O Partido Republicano Paulista: da classe ao Estado, p. 165-196.
} 
duodécimos mensais, que não devem ser excedidas senão em caso de força maior. É necessário, outrossim, extinguir, aos poucos, nas diferentes repartiçóes a numerosa classe dos empregados extranumerários ou encostados, limitando-se, assim, o pessoal de serviço nos quadros regulamentares. Quanto à imprensa, sou pela abolição do sistema de jornais subvencionado: que se auxilie, de vez em quando, com publicaçóes úteis e oportunas as folhas amigas; mas nada de subvençôes fixas, que desprestigiam os governos e oneram grandemente os cofres públicos. Neste particular, só toleraria uma exceção, em favor do "Correio Paulistano", órgão oficial do Partido e oficioso do governo (...). Quanto ao mais, que se seguissem, insaciavelmente, as sábias e prudentes normas deixadas pelo meu ilustre antecessor de cuja política e de cuja administração eu me honrava em afirmar-me discípulo e continuador. ${ }^{70}$

No programa apresentado destaca a austeridade nos gastos públicos, seja por meio da necessidade premente de diminuição do montante de despesas orçadas ou por intermédio de uma reforma administrativa. Mostra-se irredutível no que tange à subvenção oficial de órgãos da imprensa, considerando aquilo que se tornara prática habitual dos governos como antiético e imoral.

Entre as intenções presentes no discurso e sua efetivação em meio às conveniências e aos acordos políticos havia, é claro, uma enorme distância. Como membro de um partido único e regional, com características profundamente oligárquicas e patrimonialistas, Altino jamais deixou de considerar a importância dos laços de parentela, do favoritismo e da barganha como fatores de peso considerável no jogo político. ${ }^{71}$

Assim, cede em diversos momentos a essas práticas. Em trecho significativo, um pedido feito por liderança expressiva do diretório municipal da Capital envolvendo a indicação de um parente é plenamente atendido. Segue-se o comprometedor convite pessoal, desenlace das inter-relaçóes de parentelas que pesava, mormente, nas decisóes administrativas:

31 de Agosto [1916] — Pela manhã, fui procurado pelo Valois [de Castro], chegado hoje mesmo do Rio, e pelo [coronel] José Piedade. Aquele pediu-me a prometida nomeação de uma sua sobrinha para uma escola de S. Bernardo; e este convidou-me para padrinho de casamento de sua filha [Maria]. No despacho com o Cardoso, este tratou do caso político de Botucatu, mostrando-se interessado num acordo em que entrassem, em igualdade de condiçóes, seus amigos daquela localidade. ${ }^{72}$

Em alguns casos, as ligaçóes familiares e de amizade poderiam influir no afastamento de determinado indivíduo, e mesmo provocar choques desagradáveis entre novos e antigos membros do governo levando à intervenção do presidente no caso:

\footnotetext{
${ }^{70}$ Aesp. Apaa. Lócus: AP91.01.001. v. 1 [2-5-1916].

${ }^{71}$ LOVE, Joseph. A locomotiva, op. cit. p. 163.

${ }^{72}$ Aesp. Apaa. Lócus: AP91.01.001. v. 1 [31-8-1916]
} 
No despacho do Candido Motta, este comunica-me que havia readmitido, na Secretaria da Agricultura, o antigo funcionário R. Siqueira Campos, dispensado em [tempos] pelo Paulo de Moraes, ${ }^{73}$ que, por esse motivo, fora, recentemente, vítima de uma tentativa de uma agressão por parte daquele senhor. Disse ao Motta que eu ignorava completamente este último incidente; e que, por causa dele tão somente, me parecia que a readmissão do Sr. Siqueira Campos poderia prestar-se a críticas aparentemente fundadas contra o governo atual que, por tal forma, esquecia um ato reprovável de pública indisciplina. O Motta retrucou que tratavase de um pobre chefe de família honrado e trabalhador, em situação de desespero por falta de recursos; e que ele, Motta, mantendo relações formais com a família Moraes Passos, estava em condições de bem explicar ao Paulo os motivos de seu ato. ${ }^{74}$

Em determinados momentos tinha-se a impressão de que nada parecia escapar à esfera do Poder Executivo estadual, como se pode perceber no relato que se segue contendo um minucioso descritivo das articulaçóes político-partidárias em que o presidente acabava se envolvendo:

Esteve no Palácio comigo o Rodolfo Miranda tratando dos casos eleitorais da Capital, de Piracicaba e de Santa Bárbara. O Eloy, Oscar e o Fontes Junior combinavam uma ação conjunta no sentido de realizar-se um congraçamento político em Pindamonhangaba. Recomendei ao Eloy que chamasse a esta Capital o delegado de Barretos para dar-lhe instruçóes precisas categóricas sobre o próximo pleito, que desejo corra absolutamente livre. Acertei com o Cardoso a redação do termo a ser lavrado para desobrigar a Prefeitura da Capital do débito de adiantamentos, que já lhe fez o Estado, em valor superior a três mil contos. Nos Campos Elíseos encontrei o André, que falou longamente sobre a política local de Franca ou, melhor, sobre suas divergências com o Tesiano. ${ }^{75}$

A resolução de terminar com os subsídios aos jornais e opúsculos manifestados no programa de governo, mantendo intocada a exclusividade ao noticioso do partido, foi reafirmada na resposta a uma solicitação de auxílio financeiro feita por um prócer do partido:

O Senador Lacerda Franco fala-me sobre a situação precária das finanças do "Commercio de S. Paulo" ${ }^{76}$ jornal que ele adquiriu por consciência política e cuja manutenção lhe está custando um prejuízo mensal de cerca de 5 contos de réis. Pede uma subvenção do governo ou

\footnotetext{
${ }^{73}$ Paulo de Morais Barros ocupou a secretaria da Agricultura no governo de Rodrigues Alves entre julho de 1913 e novembro de 1915.

${ }^{74}$ Aesp. Apaa. Lócus: AP91.01.001. v. 1 [13-6-1916]

75 Aesp. Apaa. Lócus: AP91.01.001. v. 4 [13-6-1917].

${ }^{76} \mathrm{O}$ senador Antonio de Lacerda Franco nasceu em Itatiba (SP), em 1853, era fazendeiro e filho do barão de Araras. Fez parte por longos anos da Comissão Diretora do PRP. Presidente e fundador do Banco União e da Cia. Telefônica de S. Paulo, era também diretor do Correio Paulistano e proprietário do jornal O Comércio de S. Paulo.
} 
tratará de vender a folha, para o que lhe não faltam pretendentes. Respondo-lhe que, durante o meu governo, não subvencionarei jornal algum, a não ser o "Correio Paulistano", órgão tradicional do partido; recomendarei, entretanto, aos meus quatro Secretários que, segundo as oportunidades, mandem publicaçóes oficiais ou de interesse público ao "Comércio", pagandoos pelos preços usuais. ${ }^{77}$

Na verdade, alguns noticiosos com posição claramente governista, além do oficial Correio Paulistano, gozavam de apoio. Este variava da facilidade na negociação de empréstimos para salvar suas operaçóes, como o foi o caso do Commercio de S. Paulo, ${ }^{78}$ até a simples subvenção ( $A$ Gazeta e $A$ Nação $)^{79}$ ou mesmo o aumento do valor repassado diante da "precária situação" alegada pelo dono de $O$ Paiz. ${ }^{80}$ Por outro lado, a convivência com os jornais de oposição era tensa, queixando-se frequentemente o presidente dos ataques desferidos principalmente pelo $O$ Estado de S. Paulo, e por alguns de orientação anarquista e socialista como O Combate e Fanfulla.

Ao mesmo tempo que Altino projeta em seu diário a imagem de um político honesto, escancarava o modus operandi da máquina administrativa pública no qual os acordos de bastidores e as trocas de favores eram uma prática comum. Na verdade, tais valores eram aceitos à época e se coadunavam com uma suposta representação ideal de um político da Primeira República caracterizado pela mistura entre o mundo público e dos interesses privados.

\section{Presidente de Estado de "um país, outro país”}

Além de atuar na esfera estadual, Altino recebia frequentemente em reunióes protocolares a visita de outros governadores, políticos e oligarcas, que vinham consultar-lhe a respeito de disputas eleitorais, apoio para aprovação de projetos e recursos junto ao governo federal e diversos outros assuntos de relevância nacional.

Em abril de 1917, ocorreu a visita oficial do ex-presidente da República Nilo Peçanha a São Paulo. Em seu diário, Altino destacou que o tema mais importante da conversa entre ambos teria sido a sucessão de Wenceslau Brás e a solução para a crise aberta por Lauro Müller, ministro das Relaçóes Exteriores, devido à sua enfática defesa da neutralidade brasileira em relação ao conflito europeu. ${ }^{81}$ Pressionado pela imprensa e atacado pelos discursos de Rui Barbosa, acabaria se exonerando do cargo pouco depois. ${ }^{82}$

\footnotetext{
77 Aesp. Apaa. Lócus: AP91.01.001. v. 1 [7-6-1916].

${ }^{78}$ Aesp. Apaa. Lócus: AP92.01.001. v. 6 [6-11-1917].

${ }^{79}$ Aesp. Apaa. Lócus: AP92.01.001. v. 4 [25-5-1917]; v. 6 [16-11-1917]. Ambos subvencionados pela Secretaria de Segurança Pública.

${ }^{80}$ Aesp. Apaa. Lócus: AP92.01.001. v. 6 [22-11-1917].

${ }^{81}$ Aesp. Apaa. Lócus: AP91.01.001. v. 4 [25-5-1917].

${ }^{82}$ Aesp. Apaa. Lócus: AP91.01.001. v. 4 [3-5-1917].
} 
A questão sucessória passava a ocupar inúmeras páginas do diário, embora Altino, cada vez mais empenhado na composição da chapa que seria encabeçada por Rodrigues Alves, ponderasse a respeito dos riscos envolvidos na empreitada, conforme revela sua conversa com o senador Azeredo:

(...) entendia que devíamos todos estar prevenidos contra qualquer sucesso imprevisto, que pudesse acarretar a modificação daquela fórmula em benefício de algum candidato mineiro. "Em torno da idade avançada do Conselheiro Rodrigues Alves (disse o Senador) agitase um mundo de ambiçôes: a ambição irrequieta do Seabra; a ambição ardorosa do Nilo; a ambição coleante do Lauro; a ambição vaidosa do Ruy; a ambição sorrateira do F ${ }^{\text {co }}$ Salles... (os qualificativos são textuais). Daí a necessidade de mantermos um entendimento seguro que, na hipótese de um fracasso, nos conserve unidos e aptos para fazermos vingar candidato nosso" ${ }^{83}$

A oficialização da candidatura viria com a Convenção Republicana realizada em junho na capital federal, algo que pareceu trazer algum alívio temporário a Altino, que se desgastara no processo de negociação: "Com este resultado, que restitui ao Estado de São Paulo a sua hegemonia política na federaçáo considero terminada a missão de meu governo na ordem externa. Resta agora a parte administrativa, porventura a mais difícil e penosa..." ${ }^{84}$

Interessante notar a expressão utilizada por Altino neste episódio, ao considerar concluído os assuntos que diziam respeito à "ordem externa", dando a entender que Sáo Paulo constitui-se em sua magnitude "um país; outro país" ${ }^{85}$ Utiliza o termo "hegemonia" para se referir ao que parece interpretar como retorno ao poder dos paulistas, ignorando completamente a existência de uma chapa concorrente, pois estava convicto de que o conselheiro seria eleito.

A costura de uma aliança política em favor do conselheiro passou pelo apoio de gaúchos e mineiros, que pareciam preferir inicialmente Rui Barbosa. Antônio Azeredo, presidente de Mato Grosso, chegou a advertir Altino de uma reviravolta caso o conselheiro morresse, devido à sua idade avançada, pois receava o poder nas mãos dos mineiros. ${ }^{86}$ Essa previsão tornou-se real com o desenrolar dos acontecimentos: Rodrigues Alves foi eleito presidente em março de 1918, derrotando Nilo Peçanha; contraiu gripe do tipo espanhola ficando impedido de tomar posse; devido ao agravamento da doença, acaba falecendo em janeiro de 1919. O mineiro Delfim Moreira assumiu a presidência interinamente, como previa a Constituição, até que fosse convocada nova eleição.

Nesse novo processo sucessório, diversas candidaturas foram aventadas sem se chegar a um consenso. A candidatura de Altino acabou sendo anulada dentro de seu próprio partido,

\footnotetext{
${ }^{83}$ Aesp. Apaa. Lócus: AP91.01.001. v. 4 [2-4-1917].

${ }^{84}$ Aesp. Apaa. Lócus: AP91.01.001. v. 4 [8-6-1917].

${ }^{85}$ FRANCO, Afonso Arinos de Melo. Rodrigues Alves, op. cit. v. 2, p. 882.

${ }^{86}$ Ibid., p. 792-818.
} 
por não conseguir congregar todas as correntes do PRP, e ter sua indicação recusada pelos mineiros. Como Artur Bernardes, presidente de Minas, resolveu primeiramente se fortalecer dentro de seu estado, a escolha recaiu sobre um candidato de um estado fraco e submisso aos seus interesses. ${ }^{87} \mathrm{Bem}$ antes, Altino chegou a apontar para essa solução na eventualidade de uma crise institucional e se empenhou bastante para efetivá-la:

O Ripper, depois de ter almoçado hoje comigo, entreteve-se demoradamente em expor-me as suas apreensōes quanto à política geral, para a hipótese — que Deus não permitirá se verifique — de não poder o Conselheiro Rodrigues Alves, por seu estado de saúde, assumir a Presidência da República. Manifestei-lhe, então, como já o havia feito ao Álvaro, o meu modo de pensar a respeito, a saber: que, se a conjectura desastrosa viesse a realizar-se, os políticos de São Paulo, no interesse do Estado, deviam escolher um destes dois caminhos - ou promover o VicePresidente Delfim Moreira, ou levantar a candidatura de um representante prestigioso de algum Estado pequeno da Federação. Exemplifiquei: O Dr. Urbano dos Santos, do Maranhão, ou o Dr. Epitácio Pessoa, da Paraíba... ${ }^{88}$

Um ponto de destaque nas relaçôes de âmbito externo de São Paulo dizia respeito à política de valorizaçáo do café, que fora afetada profundamente pela guerra europeia. Em conversa com Paulo Prado, em junho de 1916, Altino combinou a estratégia para propaganda do produto na Rússia evidenciando a preocupação em substituir as praças tradicionais de consumo por novas opçôes, como o Japão e os Estados Unidos. ${ }^{89}$ Em outro encontro, quando discutiam a solução para o impasse sobre a retenção de navios do Lloyd Brasileiro e da venda de estoques de café em portos franceses, comentou sobre a necessidade de uma ação mais incisiva do ponto de vista diplomático, dando a entender que o governo brasileiro pouco se preocupava com uma questấo vital para os interesses paulistas:

Alude também a ação, quase nula que a nossa diplomacia desenvolveu na defesa de nossos interesses comerciais, restringidos discricionariamente pelas naçōes beligerantes. É assim que a Inglaterra acaba de limitar a importação de café, na Holanda, a quatro milhóes de sacas, em relação ao Brasil; o que constitui um precedente perigoso e altamente prejudicial aos nossos direitos. $^{90}$

Questôes delicadas e complexas como estas ocupavam o presidente paulista levando a compreendê-las como decisóes de um estadista. O que se percebe como algo frequente na narrativa do diário é o desejo de Altino de ser reconhecido como um protagonista, como

\footnotetext{
${ }^{87}$ LOVE, Joseph. A locomotiva, op. cit. p. 219-220, nota 63.

${ }^{88}$ Aesp. Apaa. Lócus: AP91.01.001. v. 6 [29-11-1917].

${ }^{89}$ Aesp. Apaa. Lócus: AP91.01.001. v. 1 [23-6-1916].

${ }^{90}$ Aesp. Apaa. Lócus: AP91.01.001. v. 1 [1ํ-7-1916].
} 
um personagem importante na trama política que constrói para sustentar seus argumentos. Em parte, sua personalidade se define por meio das relaçóes que mantém com importantes lideranças políticas com os quais sela acordos, firma pactos e toma decisóes que em sua interpretação interferiam no curso dos acontecimentos.

Artigo recebido em 25 de março de 2013 e aceito em 13 de agosto de 2013.

* Doutor em história pela Universidade Estadual Paulista "Júlio de Mesquita Filho", professor do curso de história da Universidade Estadual de Goiás, bolsista de pós-doutorado pela Fundaçáo de Amparo à Pesquisa do Estado de Goiás. Goiânia, GO, Brasil. E-mail: robsonmenper@hotmail.com.

** Doutora em história pela Universidade Estadual Paulista "Júlio de Mesquita Filho", professora adjunta da Faculdade de História da Universidade Federal de Goiás. Goiânia, GO, Brasil. E-mail: soniademagalhaes@ yahoo.com.br. 